\title{
Winter Wheat Growth and Yield Influenced by Wild Barley (Hordeum spontaneum Koch) Competition
}

\author{
R. Hamidi ${ }^{1} \&$ D. Mazaheri ${ }^{2}$ \\ ${ }^{1}$ Crop Production and Plant Breeding Department, College of Agriculture, Shiraz University, Shiraz, Iran \\ ${ }^{2}$ Crop Production and Plant Breeding Department, College of Agriculture, University of Tehran, Karaj, Iran \\ Correspondence: R. Hamidi, Crop Production and Plant Breeding Department, College of Agriculture, Shiraz \\ University, Shiraz, Iran. Tel: 98-711-613-8234. E-mail: hamidi@shirazu.ac.ir
}

Received: January 30, 2012 Accepted: February 20, 2012 Online Published: July 11, 2012

doi:10.5539/jas.v4n8p190 URL: http://dx.doi.org/10.5539/jas.v4n8p190

\begin{abstract}
Field experiment was conducted at Karaj, Iran to evaluate the growth and yield responses of winter wheat to various densities of wild barley and nitrogen $(\mathrm{N})$ application rates. The experimental design was split-plot with 3 replications. The main factor was four $\mathrm{N}$ levels of $0,130,260$, and $390 \mathrm{~kg}$ Urea per ha and the sub factor was weed densities. Results showed that in unfertilized plots, wild barley densities of 80 and 160 plants per sq. meter significantly decreased wheat plant height, LAI and tillers. In comparison to excess $\mathrm{N}$ and $\mathrm{N}$ deficiency treatments, the optimal $\mathrm{N}$ rate decreased wheat LAI losses at weed densities of 80 and 160 plants per sq. m. Wild barley had greater plant height and the number of tillers per plant at densities of 20 and 40 plants per sq. meter. At $130 \mathrm{~kg} \mathrm{~N}$ per ha, weed densities of 20,40, and 80 plants per sq. meter did not reduce the number of crop ear compared to hand-weeded plots. On unfertilized plots with 40, 80, and 160 weed plants per sq. meter, the reduction in number of grains per ear were 18 and 38\%, respectively. Nitrogen rates of 130 and $260 \mathrm{~kg}$ per ha increased crop and weed GNCs, whereas their STNCs were increased by N rate up to of $390 \mathrm{~kg}$ per ha. Added N resulted in higher winter wheat ANUE compared to weed ANUE.
\end{abstract}

Keywords: wild barley, wheat, competitive ability, nitrogen, applied $\mathrm{N}$ use efficiency

\section{Introduction}

Competition from weeds is the most important of all biological factors that reduce agricultural crop yield. This occurs primarily because weeds use resources that would otherwise be available to the crop (Zimdahl, 2004). The magnitude of yield loss is affected by many agronomic and environmental factors, but most importantly by the weed density, and time of emergence relative to the crop (Zimdahl, 2004). The three most commonly limiting nutrients for plants growth and development are nitrogen $(\mathrm{N})$, phosphorus $(\mathrm{P})$ and potassium $(\mathrm{K})$. Usually, $\mathrm{N}$ is the first nutrient to become limiting as a result of crop-weed competition because crops and weeds have the same basic nutrient requirements (Zimdahl, 2004).

Weeds reduce crop yield and profits by competing with the crop for soil moisture and nutrients, light, $\mathrm{CO}_{2}$ and space (Klingman \& Ashton, 1982). Yield loss and harvest problems caused by weeds in wheat will vary depending on the weed species, weed population, time of weed emergence, growing conditions and status of the wheat crop (Klingman \& Ashton, 1982). The effects of weed density, N fertilizer, crop planting date, and weed emergence on competition between wheat and blackgrass (Alopecurus agrestis L.) was studied by Exley and Snaydon (1992). Results showed that root competition affected the growth of wheat and blackgrass more than shoot competition. If either species emerged later than the other, its competitive ability was reduced.

Cultural weed control methods are becoming more important where efficacious herbicides are limited or herbicide resistance has become prevalent (Gill \& Blacklow, 1984). Soni and Ambasht (1977) found that the reduction in the concentration of $\mathrm{N}$ and $\mathrm{P}$ in the wheat plant started at the vegetative stage itself due to interference from weeds in the weedy stand and the maximal reduction was at the flowering stage (perhaps due to the maximal density of weeds at this stage), and concluded that weeds growing along with crop plants significantly affect the mineral status of the crop as well as uptake, return and retention by wheat plants.

Winter cereals were generally more effective at suppressing weed growth than spring cereals if a good crop stand was established, but overlap in weed-competitive ability among cultivars was considerable (Brain et al., 2010). 
This information can be used to enhance the sustainable production of winter and spring cereals in traditional and nontraditional agroecosystems (Brain et al., 2010). Wells (1979) studied the effect of five weed species densities on the yield of a wheat crop at three levels of applied nitrogen and found that applied nitrogen increased wheat yields at all levels of $\mathrm{N}$, but weed competition was not affected.

Manipulating crop fertilization could be an alternative method of reducing weed interference for crop yields (Blachshaw et al., 2004). Nitrogen fertilizer can break seed dormancy of certain weed species (Di Tomaso, 1995) and this may directly affect weed infestation densities. Added $\mathrm{N}$ can markedly alter crop-weed competitive interactions. Depending on the species and density, $\mathrm{N}$ fertilizer can increase the competitive ability of weeds more than that of crop (Carlson and Hill, 1985).

DiTomaso (1995) verified the assumption that weeds are more competitive than most crops at higher soil fertility levels, and weeds commonly accumulate higher concentrations of the principal fertility elements such as N, P, K, and others (calcium and magnesium). Most studies have been designed to determine the extent of yield reduction by relationship of specific weeds at known density. The relationship between weed density and crop yield vary with year, location, and environment (Aldrich, 1987).

The extent of wheat yield losses varies with duration of weed interference, weed presence, and weed density (Zimdahl, 2004). The interference of downy brome (Bromus tectorum) was studied in winter wheat by Stahlman and Miller (1990). When downy brome emerge within 14 days after wheat emergence, densities of 24, 40, or 65 weeds per sq. meter reduced wheat yield 10,15 , or $20 \%$, respectively.

Mamolos and Kalburtji (2001) found over 4 years that Canada thistle (Cirsium arvense L.) densities of 0, 4, 16, or 64 plants per sq. meter and $\mathrm{N}$ concentrations were the main factor in wheat yield reduction. Hamidi et al. (2010a) found that wild barley (H. spontaneum Koch) is a strong competitor for $\mathrm{N}$ in wheat fields of Fars province of Iran.

Wild barley is a dominant troublesome weed in most wheat fields of Fars province (Jamali \& Termeh, 1998) and other parts of Iran (Nevo et al., 1986), and its natural populations have been reported in many other parts of the world (Harlan \& Zohary, 1966; Moh'd et al., 2003). The most likely reasons for its prevalence in wheat fields are similar growth period than wheat, earlier dispersal of seeds, ability of seeds to remain dormant in the soil, and the lack of effective herbicides for its control in winter wheat. Since conventional weed management caused serious problems for environment due to water and soil pollutions, culturally and ecologically based alternative ought to be examined and tested (Liebman \& Dyck, 1993).

An understanding of the effect of agronomic managements including fertilizer rates as well as methods and time of application, is highly required to have a better understanding of the interaction between wild barley and winter wheat in Karaj, center of Iran. The objectives of this study were: 1) to evaluate the effect of wild barley competition on wheat yield and related components, and 2) to evaluate the impact of $\mathrm{N}$ rates and weed densities on winter wheat and wild barley $\mathrm{N}$ contents.

\section{Materials and Methods}

This experiment was conducted on the Experimental Station of College of Agriculture at Karaj, Iran $\left(50^{\circ} 32^{\prime} \mathrm{E}\right.$, $35^{\circ} 47^{\prime} \mathrm{N}$, and 1261 meters above the mean sea level). Average per month for temperatures, relative humidity, and precipitation is shown in Table 1.

Table 1. Monthly precipitation accumulated and average temperature and relative humidity during the winter wheat growing season at Karaj, Iran

\begin{tabular}{ccccc}
\hline Years & Months & Rainfall $(\mathbf{m m})$ & Temperature $\left({ }^{\circ} \mathbf{C}\right)$ & Relative Humidity (\%) \\
\hline \multirow{2}{*}{2004} & October & 4 & 16.9 & 50 \\
& November & 40.4 & 9.8 & 65 \\
& December & 33 & 2.2 & 74 \\
\hline \multirow{6}{*}{2005} & January & 39.6 & 2.5 & 75 \\
& February & 68 & 0.3 & 73.6 \\
& March & 52.7 & 9.6 & 54 \\
& April & 38.3 & 15.2 & 42 \\
& May & 33.4 & 18.7 & 47 \\
& June & 0.3 & 24.4 & 37 \\
& July & 0.8 & 28.3 & 37 \\
& August & 3.5 & 26.4 & 42 \\
& September & 2 & 25.8 & 46 \\
\hline Mean & & $\mathbf{2 6 . 3 3}$ & $\mathbf{1 5}$ & $\mathbf{5 3 . 5 5}$
\end{tabular}


The soil was Xeric Haplocambids (fine loamy, mixed, Semiactive, Thermic) composed of $28 \%$ sand, $39.4 \%$ silt, $32.6 \%$ clay, with $0.96 \%$ organic matter, $0.07 \%$ total $\mathrm{N}, 8.8 \mathrm{mg}$ per kg available $\mathrm{P}_{2} \mathrm{O}_{5}, 200 \mathrm{mg}$ per kg exchangable $\mathrm{K}_{2} \mathrm{O}$, and a pH of 8 .

The winter wheat (Triticum aestivum L.) cultivar "Pishtaz" was sown by grain driller to a depth of 3-5 $\mathrm{cm}$ in the field. The seeding rate was $180 \mathrm{~kg}$ per ha in rows spaced $20 \mathrm{~cm}$ apart. Sufficient quantities of wild barley non-dormant seeds were planted by hand between the rows, and after emergence, thinned to obtain particles densities. Triple super phosphate at $200 \mathrm{~kg}$ per ha and potassium sulfate at $150 \mathrm{~kg}$ per ha were applied before planting. The experimental design was a split-plot with four replications. The main factor was $\mathrm{N}$ levels $(0,130$, 260 , and $390 \mathrm{~kg}$ Urea per ha) which was applied of pre-plant (1/3 ) and jointing stage (2/3). The sub factor was five wild barley density levels $(0,20,40,80$, and 160 plants per sq. meter). The size of each subplot was $2 \times 6 \mathrm{~m}$ containing 10 rows of winter wheat.

All weeds were removed by hand (hand-weeded plots) until winter wheat canopy closure wild barley.

Table 2. Days after planting of wheat and wild barley and their corresponding growth stages at Experimental Station Farm, College of Agriculture, Karaj, Iran

\begin{tabular}{ccccc}
\hline Growth stage & Winter wheat & Wild barley & $\mathbf{N}$ application time & \\
\hline Emergence & 7 & 12 & Pre-plant & $1 / 3,1^{\text {st }} \mathrm{N}$ application \\
Full tillering & 82 & 60 & & \\
Jointing & 165 & 148 & 130 & $2 / 3,2^{\text {nd }} \mathrm{N}$ application \\
Heading & 202 & 182 & & \\
Ripening & 239 & 213 & & \\
Harvesting & 240 & 209 & & \\
\hline
\end{tabular}

Since winter wheat and wild barley did not simultaneously mature (Table 2), wild barley plants were harvested earlier than wheat. Winter wheat and wild barley plants were separately harvested at the soil surface from 1 sq. meter of the middle of 4 rows in each subplot. For winter wheat, morphological traits including plant height, number of tillers per plant and leaf area index (LAI); yield and other related components such as grain weight per plant, number of ear per sq. meter, number of seeds per ear, and 1000-grain weight, and, for wild barley, morphological traits including plant height, number of tillers per plant, LAI, relative leaf area (Lw), and grain (caryopsis) weight per plant were measured. Lw was computed as following relationship (Kropff \& Spitters, 1991):

$$
\mathrm{Lw}=\mathrm{LAI}_{\text {weed }} / \mathrm{LAI}_{\text {crop }}+\mathrm{LAI}_{\text {weed }}
$$

Where: $\mathrm{Lw}$ is relative leaf area, $\mathrm{LAI}_{\text {crop }}$ and $\mathrm{LAI}_{\text {weed }}$ are the LAI of the crop and weed, respectively.

Total $\mathrm{N}$ concentration (\%) was determined by the micro-Kajeldal methods (Nelson and Sommer, 1972) for both plant species, $\mathrm{N}$ yields including grain $\mathrm{N}$ yield (GNY), straw $\mathrm{N}$ yield (STNY), applied $\mathrm{N}$ use efficiency (ANUE) were computed using the basic data measured as follow (Sinebo et al., 2004):

$$
\begin{aligned}
& \text { GNY }(\text { g per plant })=\text { grain N concentration }(\mathrm{GNC}) \times \text { grain yield }(\mathrm{GRYD}) \\
& \text { STNY }(\text { g per plant })=\text { straw N concentration }(\mathrm{STNC}) \times{ }_{\text {straw yield }}(\mathrm{STRY}) \\
& \text { ANUE }(\mathrm{g} \text { per } \mathrm{g} \text { per plant })=\left(\mathrm{GRYD}_{\mathrm{f}}-\mathrm{GRYD}_{0}\right) / \mathrm{N}_{\mathrm{f}}
\end{aligned}
$$

Where GRYD $\mathrm{D}_{\mathrm{f}}$ is the grain yield with fertilizer $\mathrm{N}$ in a weed density treatment and $\mathrm{GRYD}_{0}$ is the corresponding yield without $\mathrm{N}$ fertilizer application in the same weed density. $\mathrm{N}_{\mathrm{f}}$ is the level of fertilizer $\mathrm{N}$ applied which were 13,26 , and 39 g per sq. meter.

All data were analyzed using ANOVA and means were separated by Duncan's new multiple range test at the $\mathrm{p}=0.05$ level.

\section{Results and Discussion}

\subsection{Morphological Traits}

Maximum losses for winter wheat plant height due to wild barley competition on unfertilized plots occurred at the density of 160 weeds per sq. meter. At this density, maximum suppression was also found in wheat tillers per plant and LAI as compared to weed-free plots (Table 3). With increasing $\mathrm{N}$ level, all winter wheat morphological traits decreased. In comparison to high $\mathrm{N}$ level (390 kg Urea per ha) and N deficiency ( $0 \mathrm{~kg}$ Urea per ha) treatments, the 
optimal $\mathrm{N}$ rate (130 kg Urea per ha) decreased winter wheat LAI at wild barley densities of 80 and 160 plants per sq. meter (Table 3).

Table 3. Wheat plant height, tillers per plant and leaf area index (LAI) shown as percent by using control treatment as reference for the wild barley population densities and $\mathrm{N}$ application rates at Karaj, Iran

\begin{tabular}{|c|c|c|c|c|}
\hline \multirow[t]{2}{*}{$\mathrm{N}$ application rates (kg per ha) } & \multirow[t]{2}{*}{ Wild barley density (plants per sq. m) } & \multicolumn{3}{|c|}{ Wheat morphological traits ${ }^{\dagger}(\%)$} \\
\hline & & Plant height & Tillers per plant & LAI \\
\hline 0 & 0 & 100 & 100 & 100 \\
\hline 0 & 20 & 99 & 94 & 97 \\
\hline 0 & 40 & 83 & 94 & 97 \\
\hline 0 & 80 & 75 & 73 & 82 \\
\hline 0 & 160 & 65 & 57 & 72 \\
\hline 130 & 0 & 100 & 100 & 100 \\
\hline 130 & 20 & 94 & 100 & 100 \\
\hline 130 & 40 & 93 & 97 & 97 \\
\hline 130 & 80 & 88 & 91 & 88 \\
\hline 130 & 160 & 84 & 85 & 76 \\
\hline 260 & 0 & 100 & 100 & 100 \\
\hline 260 & 20 & 96 & 100 & 97 \\
\hline 260 & 40 & 95 & 94 & 96 \\
\hline 260 & 80 & 88 & 88 & 88 \\
\hline 260 & 160 & 79 & 85 & 69 \\
\hline 390 & 0 & 100 & 100 & 100 \\
\hline 390 & 20 & 97 & 100 & 97 \\
\hline 390 & 40 & 95 & 88 & 93 \\
\hline 390 & 80 & 90 & 85 & 72 \\
\hline 390 & 160 & 87 & 79 & 64 \\
\hline
\end{tabular}

${ }^{\dagger}$ Weed-free treatment at each $\mathrm{N}$ application rate was conducted and it was taken as reference (100\%).

Table 4. Winter wheat yield and related components shown as percent by using control treatment as reference for the wild barley population densities and $\mathrm{N}$ application rates at Karaj, Iran

\begin{tabular}{|c|c|c|c|c|c|}
\hline \multirow{2}{*}{$\begin{array}{c}\mathrm{N} \text { application rates } \\
\text { (kg per ha) }\end{array}$} & \multirow{2}{*}{$\begin{array}{l}\text { Wild barley density } \\
\text { (plants per sq. m) }\end{array}$} & \multicolumn{3}{|c|}{ 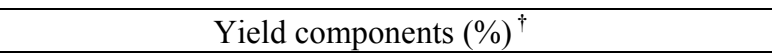 } & \multirow{2}{*}{$\begin{array}{c}\text { Grain yield } \\
(\%)^{\dagger}\end{array}$} \\
\hline & & Ears per sq. $\mathrm{m}$ & Grains per ear & 1000-grain weight & \\
\hline 0 & 0 & 100 & 100 & 100 & 100 \\
\hline 0 & 20 & 99 & 93 & 99 & 93 \\
\hline 0 & 40 & 97 & 82 & 93 & 75 \\
\hline 0 & 80 & 71 & 75 & 83 & 45 \\
\hline 0 & 160 & 65 & 62 & 59 & 25 \\
\hline 130 & 0 & 100 & 100 & 100 & 100 \\
\hline 130 & 20 & 100 & 97 & 98 & 95 \\
\hline 130 & 40 & 100 & 95 & 97 & 93 \\
\hline 130 & 80 & 98 & 87 & 86 & 74 \\
\hline 130 & 160 & 90 & 74 & 86 & 53 \\
\hline 260 & 0 & 100 & 100 & 100 & 100 \\
\hline 260 & 20 & 99 & 93 & 99 & 96 \\
\hline 260 & 40 & 99 & 89 & 97 & 91 \\
\hline 260 & 80 & 96 & 85 & 80 & 69 \\
\hline 260 & 160 & 85 & 76 & 77 & 60 \\
\hline 390 & 0 & 100 & 100 & 100 & 100 \\
\hline 390 & 20 & 95 & 90 & 88 & 92 \\
\hline 390 & 40 & 92 & 94 & 82 & 90 \\
\hline 390 & 80 & 85 & 80 & 77 & 70 \\
\hline 390 & 160 & 77 & 65 & 60 & 58 \\
\hline
\end{tabular}

\footnotetext{
${ }^{\dagger}$ Weed-free treatment at each $\mathrm{N}$ application rate was conducted and it was taken as reference $(100 \%)$.
} 
Table 5. Wild barley plant height, tillers per plant, leaf area index (LAI), and relative leaf area (Lw) as affected by various densities of own plant and $\mathrm{N}$ application rates ${ }^{\mathrm{a}}$

\begin{tabular}{|c|c|c|c|c|c|}
\hline \multirow{2}{*}{$\begin{array}{l}\mathrm{N} \text { application rate } \\
\text { (kg Urea per ha) }\end{array}$} & \multirow{2}{*}{$\begin{array}{l}\text { Wild barley density } \\
\text { (plants per sq.m) }\end{array}$} & \multicolumn{4}{|c|}{ Wild barley morphological traits } \\
\hline & & $\begin{array}{l}\text { Plant height } \\
(\mathrm{cm})\end{array}$ & $\begin{array}{l}\text { Tillers per plant } \\
\text { (No.) }\end{array}$ & LAI & Lw \\
\hline 0 & 20 & $48.4 \mathrm{c}$ & $3.78 \mathrm{~b}$ & $0.7 \mathrm{e}$ & 0.14 \\
\hline 0 & 40 & $45.3 \mathrm{c}$ & $3.75 \mathrm{~b}$ & $1.5 \mathrm{~d}$ & 0.26 \\
\hline 0 & 80 & $40.1 \mathrm{~d}$ & $2.96 \mathrm{~d}$ & $2.3 \mathrm{c}$ & 0.39 \\
\hline 0 & 160 & $37.2 \mathrm{e}$ & $2.11 \mathrm{e}$ & $3.4 \mathrm{~b}$ & 0.51 \\
\hline 130 & 20 & $58.9 \mathrm{a}$ & $4.52 \mathrm{a}$ & $0.9 \mathrm{e}$ & 0.1 \\
\hline 130 & 40 & $58.2 \mathrm{a}$ & $4.43 \mathrm{a}$ & $1.7 \mathrm{~d}$ & 0.19 \\
\hline 130 & 80 & $53.0 \mathrm{~b}$ & $3.12 \mathrm{c}$ & $2.5 \mathrm{c}$ & 0.25 \\
\hline 130 & 160 & $48.6 \mathrm{c}$ & $2.98 \mathrm{~d}$ & $4.7 \mathrm{a}$ & 0.45 \\
\hline 260 & 20 & $58.9 \mathrm{a}$ & $4.66 \mathrm{a}$ & $0.9 \mathrm{e}$ & 0.11 \\
\hline 260 & 40 & $58.7 \mathrm{a}$ & $4.53 \mathrm{a}$ & $1.8 \mathrm{~d}$ & 0.19 \\
\hline 260 & 80 & $53.8 \mathrm{~b}$ & $3.18 \mathrm{c}$ & $2.5 \mathrm{c}$ & 0.27 \\
\hline 260 & 160 & $49.0 \mathrm{c}$ & $2.90 \mathrm{~d}$ & $4.6 \mathrm{a}$ & 0.46 \\
\hline 390 & 20 & $59.2 \mathrm{a}$ & $4.41 \mathrm{a}$ & $0.8 \mathrm{e}$ & 0.1 \\
\hline 390 & 40 & $59.0 \mathrm{a}$ & $4.36 \mathrm{a}$ & $1.7 \mathrm{~d}$ & 0.2 \\
\hline 390 & 80 & $54.0 \mathrm{~b}$ & $3.21 \mathrm{c}$ & $2.5 \mathrm{c}$ & 0.32 \\
\hline 390 & 160 & $49.2 \mathrm{c}$ & $2.82 \mathrm{~d}$ & $4.5 \mathrm{a}$ & 0.40 \\
\hline
\end{tabular}

${ }^{a}$ Means within each column with the same letter are not significantly different at the 0.05 level according to Duncan`s new multiple range test.

Wild barley had greater plant height and the number of tillers per plant at densities of 20 and 40 plants per sq. meter on fertilized plots than unfertilized treatments (Table 5). No significant differences were observed between weed plant heights at densities of 20 and 40 plants per sq. meter on both unfertilized and fertilized plots. This also happen for number of tillers per plant. Wild barley LAI increased with increasing its density and maximum LAI was observed at density of 160 plants per sq. meter. Relative leaf area (Lw) decreased by increasing $\mathrm{N}$ application rates in all densities of wild barley which caused a decrease of crop LAI due to the weed competition (Table 5).

\subsection{Yield and Related Components}

The response ear per sq. meter, grains per ear, 1000-grain weight, and grain yield of winter wheat to various wild barley densities under different $\mathrm{N}$ application rates are shown in Table 4 . Number of ear per sq. meter recorded for plots in which wild barley densities were 20,40, and 80 plants per sq. meter were not significantly different from the hand-weeded plots at $130 \mathrm{~kg} \mathrm{~N}$ per ha. This could be happen because no competition occurred between winter wheat and wild barley at this $\mathrm{N}$ level. As $\mathrm{N}$ application rate was increased to $390 \mathrm{~kg}$ per ha, losses in number of ear per sq. meter were markedly observed at weed density treatments of 80 and 160 plants per sq. meter (Table 4). The highest losses in the number of ear per sq. meter and grains per ear were observed at wild barley density of 160 plants per sq. meter on unfertilized plots indicating the most severe competition between two plants. Similar results were obtained with 1000-grains weight. Among the winter wheat components, number of grains per ear and 1000 -grains weight were the most sensitive to the wild barley density treatments. On unfertilized plots with 40, 80, and 160 weed plants per sq. meter, the reduction in the number of grains per ear were 18,25 , and $38 \%$, respectively (Table 4).

For wheat grain yield, there were no significant differences between hand-weeded plots and wild barley densities of 20 and 40 plants per sq. meter on fertilized plots, whereas weed density of 40 plants per sq. meter significantly decreased wheat grain yield per unit area as compared to weed-free plots on unfertilized plots. As wild barley density increased, wheat grain yield decreased at both fertilized and unfertilized treatments (Table 4).

\subsection{Nitrogen Content of Winter Wheat and Wild Barley}

On unfertilized and fertilized plots, winter wheat GNY and STNY decreased with increasing wild barley density and increased with increasing $\mathrm{N}$ levels up to $260 \mathrm{~kg}$ per ha, and then decreased at $390 \mathrm{~kg}$ per ha (Figure 1 and 2). With no addition of N, wild barley GNY was more than that of wheat at all weed density (Figure 1 and 4) indicating more competitive ability of wild barley than winter wheat. Application of $130 \mathrm{~kg} \mathrm{~N}$ per ha increased winter wheat GNY at all levels of wild barley densities. At weed density of 80 plants per sq. meter, wheat and wild barley GNYs were nearly equal. Winter wheat showed more STNY than those of wild barley at all N application 
rates and weed density levels (Figure 2 and 5). Winter wheat and wild barley ANUE values showed that winter wheat used $\mathrm{N}$ more efficiently than wild barley because a higher potential for grain production (Raun and Johnson, 1999).

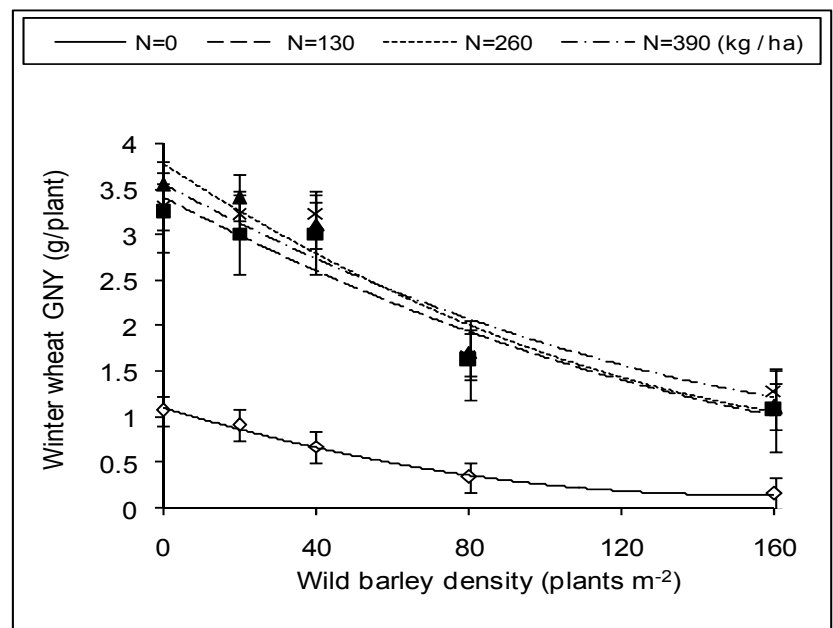

Figure 1. Winter wheat grain $\mathrm{N}$ yield (GNY) response to different wild barley densities and $\mathrm{N}$ application rates

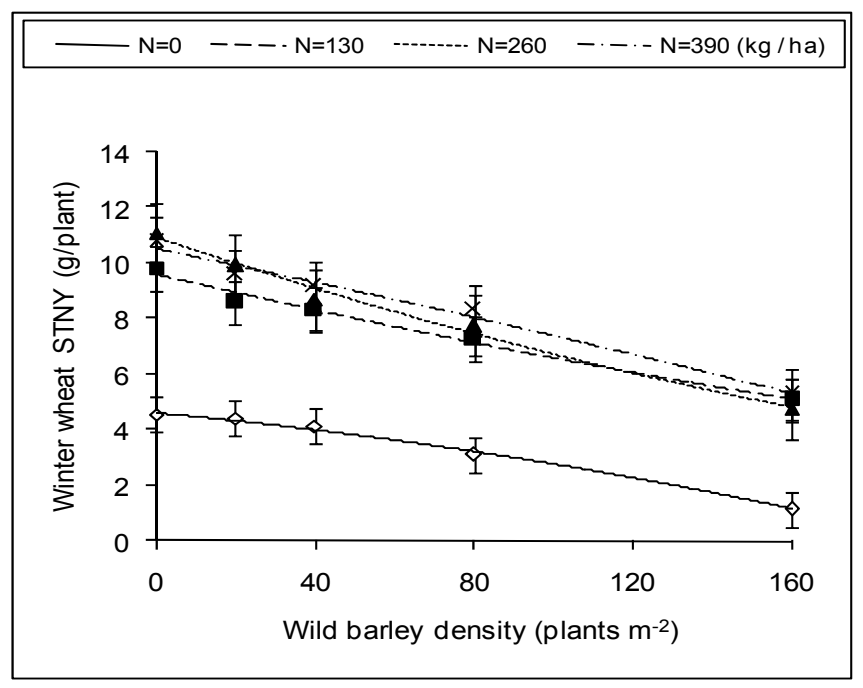

Figure 2. Winter wheat straw $\mathrm{N}$ yield (STNY) response to different wild barley densities and $\mathrm{N}$ application rates

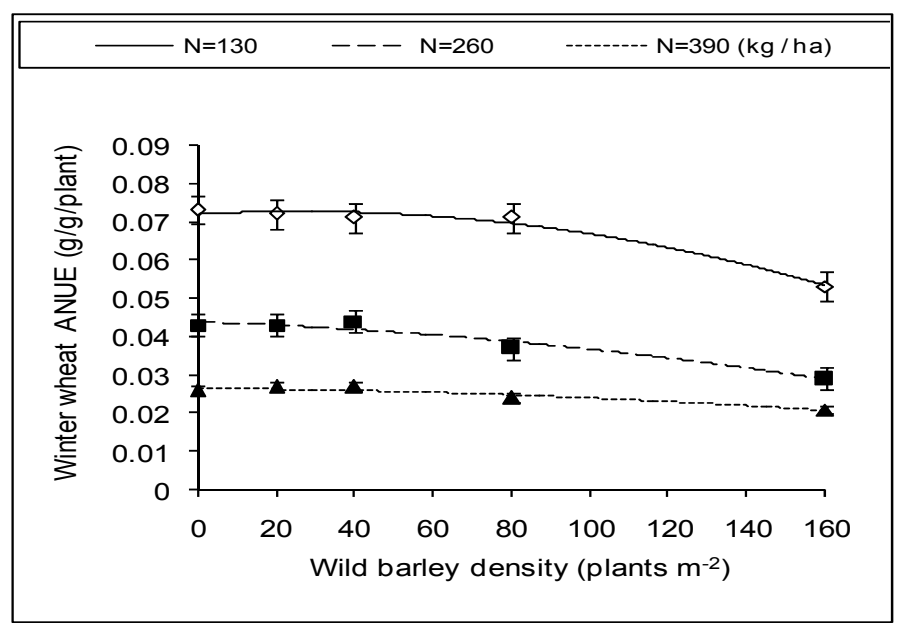

Figure 3. Winter wheat applied $\mathrm{N}$ use efficiency (ANUE) response to different wild barley densities and $\mathrm{N}$ application rates 


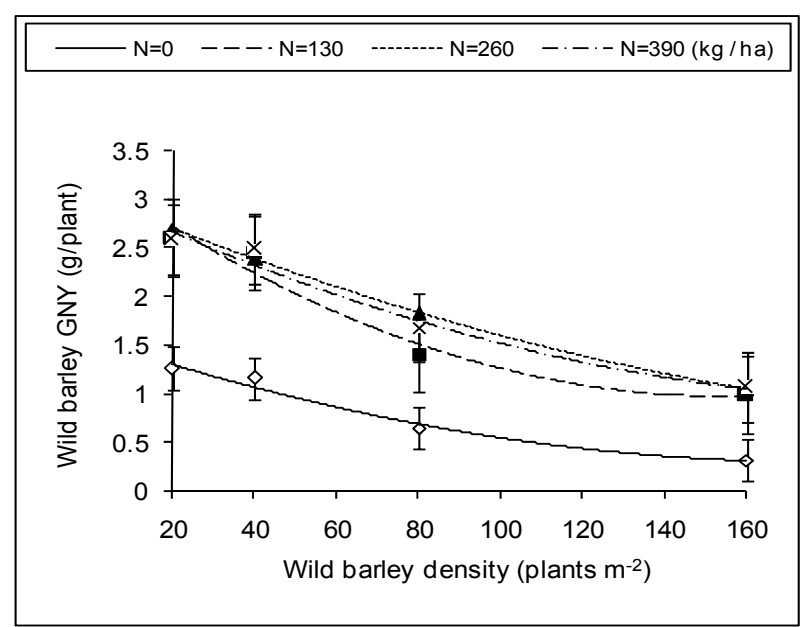

Figure 4. Wild barley grain $\mathrm{N}$ yield (GNY) response to its own densities and $\mathrm{N}$ application rates

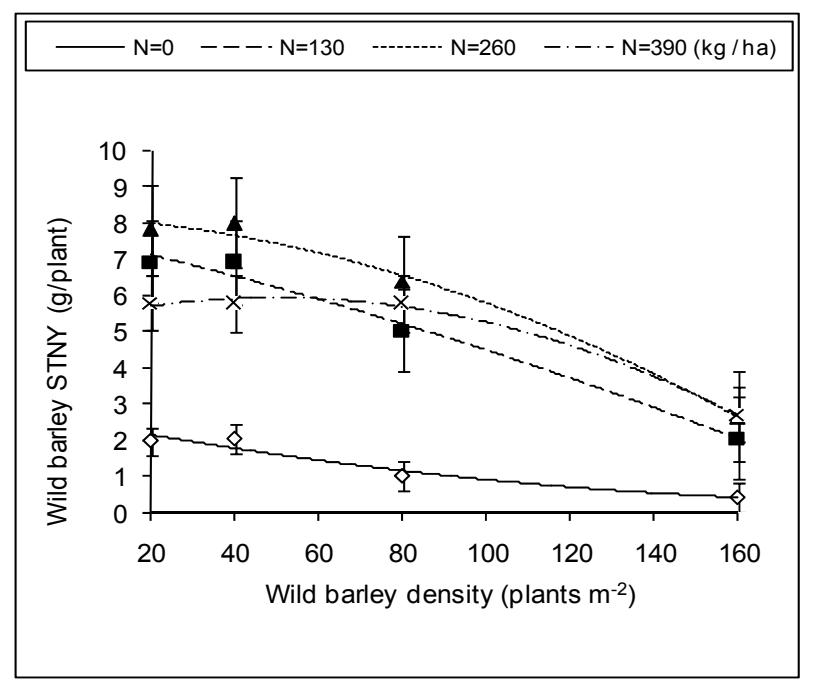

Figure 5. Wild barley straw $\mathrm{N}$ yield (STNY) response to its own densities and $\mathrm{N}$ application rates

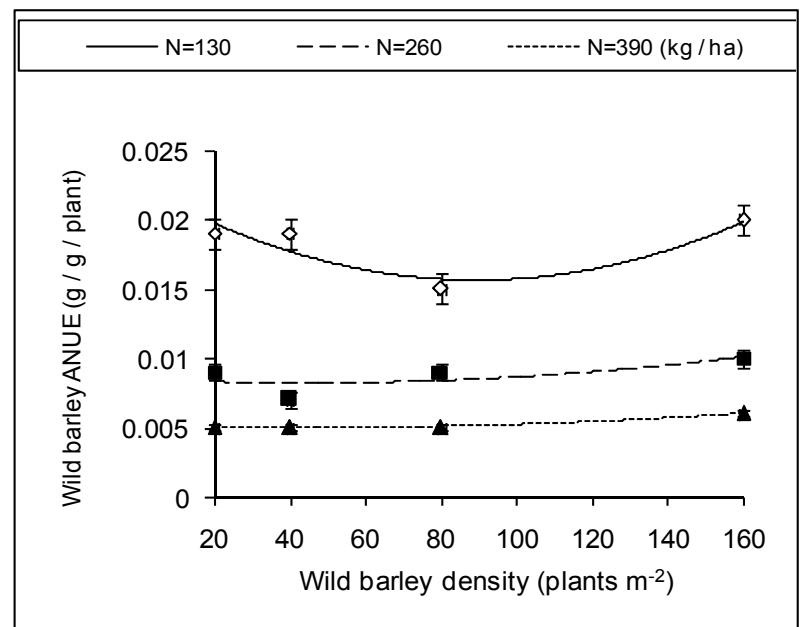

Figure 6. Wild barley applied $\mathrm{N}$ use efficiency (ANUE) response to its own densities and $\mathrm{N}$ application rates

Each level of added $\mathrm{N}$ resulted in higher winter wheat ANUE compared to wild barley ANUE, indicating higher ANUE in wheat (Figure 3 and 6) while, wild barley took up more $\mathrm{N}$ than winter wheat at all $\mathrm{N}$ application rates (Figure 3). The higher winter wheat ANUE compare to wild barley one, may to have resulted from higher wheat GNY, although wild barley had higher GNC and STNC than those of wheat (Hamidi et al., 2010b). The negative 
correlation between GRYD and GNC was reported by other studies (Cox et al., 1985; Kibite \& Evans, 1984; May et al., 1991).

It has been demonstrated in the current study that wild barley had higher competitive ability than wheat at all $\mathrm{N}$ application rates. This may be resulted from higher GNC and STNC (Shipley \& Keddy, 1988) and mechanism(s) by which it could tolerate higher levels of $\mathrm{N}$ in the soil (Huang \& Redmann, 1995; Matsuda \& Riazi, 1981). Over-applying fertilizers such as urea in the soil could increases osmotic potential the soil solution causing less water and nutrients be absorbed by plants (Brady, 1984). Cultivated and wild barley are able to tolerate osmotic stress by reducing the cellular osmotic potential as a consequence of a net increase in solute accumulation (Ali et al., 2001; Guoxiong et al., 2002; Matsuda \& Riazi, 1981). Probably the higher osmotic adjustment capacity of barley than that of wheat (Teulat et al., 1997) caused wild barley took up more $\mathrm{N}$ than winter wheat from the soil in high $\mathrm{N}$ treatments. In the previous studies, the higher competitive ability of cultivated barley than winter wheat against weeds were reported (Afentouli \& Eleftherohorinos, 1996; Bell \& Nalewaja, 1968; Morishita et al., 1989).

\section{Conclusions}

In our study that was limited to one growing season, the wild barley competition with winter wheat showed that under natural or field conditions wild barley compete with winter wheat and there is not control of population density. Wild barley is one of the most important weeds in many regions of Iran and started its growth earlier than winter wheat, and enhanced competition for nutrients. The results of this study showed that manipulating winter wheat fertilization may be one method of reducing this weed competition and in the future, wild barley control management should consider the effect of higher amounts of $\mathrm{N}$ application rates on wild barley competition because this weed took up more $\mathrm{N}$ than winter wheat. Information that has been reported in this study may be valuable and helpful to agricultural scientists, farmers, and extension officers with regard to fertilization management.

\section{References}

Afentouli, C. G., \& Eleftherohorinos, I. G. (1996). Littleseed canarygrass (Phalaris minor) and short-spiked canarygrass (P. brachystachys) interference in wheat and barley. Weed Sci., 44, 560-565.

Aldrich, R. J. (1987). Predicting crop yield reduction from weeds. Weed Technol., 1, $199-206$.

Ali, A., T. C. Tucker, T. L. Thomson, \& M. Salin. (2001). Effects of salinity and mixed ammonium and nitrate nutrition on the growth and nitrogen utilization of barley. J. Agron. Crop Sci., 186, 223-227.

Bell, A. R., \& Nalewaja, J. D. (1968). Competition of wild oat in wheat and barley. Weed Sci., 16, 505-508.

Blachshaw, R. E., Molnar, L. J., \& Janzen, H. H. (2004). Nitrogen fertilizer timing and application method affect weed growth and competition with spring wheat. Weed Sci., 52, 614-622.

Brady, N. C. (1984). The Nature and Properties of Soils. MacMillan Publishing Company, New York, pp.750.

Brian L. Beres, Harker, K. N., Clayton, G. W., Bremer, E., Blackshaw, R. E., \& Graft, R. J. (2010). Weed-Competitive Ability of Spring and Winter Cereals in the Northern Great Plains. Weed Technol., 24, 108-116.

Carlson, H. L., \& Hill, J. E. (1985). Wild oat (Avena fatua) competition with spring wheat: effects of nitrogen fertilization. Weed Sci., 34, 29-33.

Cox, M. C., Qualset, C. O., \& Rains, D. W. (1985). Genetic variation for nitrogen assimilation and translocation in wheat. I. Dry matter and nitrogen accumulation. Crop Sci., 25, 430-435.

Di Tomaso, J. M. (1995). Approaches for improving crop competitiveness through the manipulation of fertilization strategies. Weed Sci., 43, 491-497.

Exley, D. M. \& Snaydon, R. W. (1992). Effects of nitrogen fertilizer andemergence date on root and shoot competition between wheat and blackgrass. Weed Res., 32, 175-182.

Fennr, M. (1983). Relationship between seed weight, ash content and seedling growth in twenty four species of Compositae. New Phytol., 95, 697-706.

Gill, G. S. \& Blacklow, W. M. (1984). Effect of great brome (Bromus diandrus Roth.) on the growth of wheat and great brome and their uptake of nitrogen and phosphorus. Aust. J. Agric. Res., 35, 1-8.

Guoxiong, C., Krugman, T., Fahima, T., Korol, A. B., \& Nevo, E. (2002). Comparative study on morphological and physiological traits related to drought resistance between xeric and mesic Hordeum spontaneum lines. Hard copy edition, 22-33. 
Hamidi, R., D. Mazaheri \& H. Rahimian. (2010a). Effect of nitrogen on Hordeum spontaneum (Koch) competition with winter wheat. Aust. J. Basic Appl. Sci., 4, 4695-4700.

Hamidi, R., Mazaheri, D., \& Rahimian, H. (2010b). Winter wheat (Triticum aestivum L.) nitrogen yields as affected by wild barley (Hordeum spontaneum Koch) population density and nitrogen. Aust. J. Basic Appl. Sci, 4, 4726-4739.

Harlan, J. R., \& Zohary, D. (1966). Distribution of wild wheats and barley. Science, 153, 1074-1080.

Huang, J., \& Redmann, R. E. (1995). Solute adjustment to salinity and calcium supply in cultivated and wild barley. J. plant Nutr., 18, 1371-1389.

Jamali, M., \& Termeh, F. (1998). Identification of graminae weeds in fields, gardens. and pastures of Fars province. Proceeding of the $13^{\text {th }}$ Iranian Plant Protection Congress. Vol II. Plant Diseases and Weeds, 23-27 August 1998, Karaj, Iran, pp. 327.

Kibite, S., \& Evans, L. E. (1984). Cause of negative correlations between grain yield and grain protein concentration in common wheat. Euphytica, 33, 801-810.

Klingman, G. C., \& Ashton, F. M. (1982). Weed Science: Principles and Practices. John Wiley and Sons Inc., USA, pp. 449.

Kropff, M. J., Lotz, L. A. P., Weaver, S. E., Bos, H. J., Wallinga, J., \& Mig., T. (1995). A two-parameter model for prediction of crop loss by weed competition from early observations of relative area of weeds. Ann. Appl. Biol., 126, 329-346.

Liebman, M. \& Dyck, E. (1993). Weed management: A need to develop ecological approaches. Ecol. Appl., 3, $39-41$.

Mamolos, A. P. \& Kalburtji, K. L. (2001). Competition between Canada thistle and winter wheat. Weed Sci., 49, 755-759.

Matsuda, K., \& Riazi, A. (1981). stress-induced osmotic adjustment in growing rejoins of barley leaves. Plant Physiol., 68, 571-576.

May, L. D. A. Van Sanford, Mackown, C. T., \& Cornelius, P. L. (1991). Genetic variation for nitrogen use in soft red $\mathrm{x}$ hard red winter wheat population. Crop Sci., 31, 626-630.

Moh'd, K., El-Shatnawi, J., \& Ghosheh, H. Z. (2003). Interference of wild oat and wall barley on growth of Dual-purpose barley under semi-arid Mediterranean climate. Crop Res., 25, 12-20.

Morishita, D. W., Thill, D. C., \& Hammel, J. E. (1989). Wild oat (Avena fatua) and spring barley (Hordeum vulgare) growth in replacement series experiments. Weed Sci., 37, 85-89.

Nelson, D. W., \& Sommer, L. E. (1972). Determination of total nitrogen in plant materials. Agron. J., 65, 109-112.

Nevo, E., Kaplan, D., Storch, N., \& Zohary, D. (1986). Genetic diversity and environmental associations of wild barley, Hordeum spontaneum (Poaceae), in Iran. Plant Syst. Ecol., 153, 141-164.

Raun, W. R., \& Johnson, G. V. (1999). Improving nitrogen use efficiency for cereals production. Agron. J., 91, 357-363.

Shipley, B., \& Keddy, P. A. (1988). The relationship between relative growth rate and sensitivity to nutrient stress in twenty eight species of emergent macrophytes. J. Ecol., 76, 1101-1110.

Sinebo, W., Gretzmacher, R., \& Edelbauer, A. (2004). Genotypic variation for nitrogen use efficiency in Ethiopian barley. Field Crop Res., 85, 43-60.

Soni, P., \& Ambasht, R. S. (1977). Effect of crop-weed competition on the mineral structure of wheat crop. Agro-Ecosystems, 3, 325-336.

Stahlman, P. W., \& Miller, S. D. (1990). Downy brome (Bromus tectorum) interference and economic thresholds in winter wheat (Triticum aestivum). Weed Sci., 38, 224-228.

Teulat, B., Rekika, D., Nachit, M. M., \& Monneveux, P. (1997). Comparative osmotic adjustment in barley and tetraploid wheats. Plant Breeding, 116, 519-523.

Zimdahl, R. L. (2004). Weed-Crop competition. A Review, $2^{\text {nd }}$ Edition, Blackwell publishing Ltd., Oxford, UK, 220. 